\title{
The Use of Functional Indexes to Evaluate Fitness in Andalusian Horses
}

\author{
A. MUÑOZ, R. SANTISTEBAN, M. D. RUBIO, R. VIVO, E. I. AGÜERA, B. M. ESCRIBANO, and \\ F. M. CASTEJÓN \\ Department of Animal Biology, Section of Physiology, Faculty of Veterinary Medicine, University of Córdoba, C/Medina Azahara, s/n. \\ 14071 Córdoba, Spain
}

(Received 8 January 1997/Accepted 7 May 1997)

ABSTRACT. The fitness of 8 Andalusian horses between 3 and 4 years of age was analysed. The animals were subjected to an exercise test on a sandy track consisting of 2 stages of different intensities. The first stage was of submaximal intensity at 4 speeds which increased progressively $(4.17,5.56,6.94$ and $8.33 \mathrm{~m} / \mathrm{sec}$.) covering a distance of $1,000 \mathrm{~m}$ in each level. Between each of these speeds, the horses rested for $2 \mathrm{~min}$. The second stage was a maximal speed test over the same distance carried out 2 min after the ending of the maximal phase. Data of heart rate, plasma lactate concentration, velocity, $\mathrm{PCV}$ and $\mathrm{pH}$ in the blood were obtained. Maximum heart rate, maximum velocity, $\mathrm{V}_{\mathrm{LA} 2}, \mathrm{~V}_{\mathrm{LA} 4}$, peak lactate, minimum $\mathrm{pH}$ and maximum PCV were considered functional indexes. A principal component enabled us to segregate horses according to their fitness and in relation to the information provided by the trainers in charge of these horses. The most discriminant variables in order to segregate horses were $\mathrm{pHmin}, \mathrm{V}_{\mathrm{LA} 4}, \mathrm{HRmax}, \mathrm{V}_{\mathrm{LA} 2}$ and $\mathrm{Vmax}$. Differences between horses in relation to PCVmax were not found. The influence of each one of these functional indexes on the test exercise tolerance was discussed. - KEY WORDS: equine exercise, fitness, functional index.

J. Vet. Med.Sci. 59(9): 747-750, 1997

In Spain, the Army possesses many Andalusian horses, which can be used by breeding stock farms to mating their mares. The Andalusian horse is held for its beauty and fine temperament and, therefore, its selection has always been based on these qualities. For these reasons, veterinarians from the Army test the morphologic characteristics to verify that the animals have the necessary qualities to be considered as an Andalusian horse. Similarly, the trainers give a report on their easiness to handle and qualities for saddling. This last point is of vital importance, since in Spain this breed is basically used for riding.

Recently the Andalusian horse has begun to compete in classic dressage and carriage driving. A trend to potenciate its physical capacity is developing now in Spain. In consequence, an attempt might be made to reach a prognosis of future performance, i.e., the ability to perform a physical work, and this would be destined to the selection of the most physically able horses.

The means used by previous studies to evaluate exercise capacity and tolerance have varied. Electrocardiography is often considered in the diagnosis of the cause of poor performance. Morphologic characteristics in the electrocardiographic $\mathrm{T}$ wave have been related to lack of performance in apparently healthy horses [15]. Other studies have attempted to correlate the number of sporting events won by the horse with the value of "Heart Score", a presumed index of the ventricular size, calculated from the mean duration of QRS complex on the three Leads of Einthoven (I, II, III) [27]. Musculo-skeletal parameterspercentage and total number of the I, IIA and IIB fibres [25] or the enzyme activity [28] and haematological parameters have also been considered [21]. Likewise, many tests for evaluation of fitness and exercise tolerance in horse involve measuring the response to exercise of the heart rate and plasma lactate levels during exercise and recuperation
[6].

Therefore, the main aim of the present work was to describe an objective method to assess physical capacity in Andalusian horses by means of some functional indexes derived from heart rate, lactate, blood $\mathrm{pH}, \mathrm{PCV}$ and speed during a standardized exercise test (SET).

\section{MATERIALS AND METHODS}

Horses: Eight clinically healthy male Andalusian horses, between 3 and 4 years of age were studied. As all these animals belonged to the Training and Selection Center of the Military Stud at Jerez de la Frontera (Spain), their sanitary, feeding and handling conditions were extremely homogeneous. No special criterion was followed to select these animals.

The horses' daily diet consisted of a commercial fodder (3-4 kg according to the moment of training), oat, bran (3 $\mathrm{kg}$ ) and hay ad libitum. The caloric distribution of the nutrients was $12-18 \%$ nitrogenated substances, $2-4 \%$ fat and $15-25 \%$ gross fibre, which signified a caloric intake of 18,200-21,250 KJ (hay consumption not counted).

Standardized exercise test (SET): The SET was performed in two phases with different intensities, separated by a 2min rest period. 1) First phase, of submaximal intensity, divided into four workload $(4.15,5.56,6.94$ and $8.33 \mathrm{~m} /$ $\mathrm{sec}$ ), covering a distance of $1,000 \mathrm{~m}$ at each level of exercise. The horses were given a 2 min rest between each exercise bout. 2) Second phase, of maximal intensity, consisted of covering $1,000 \mathrm{~m}$ at the maximal velocity.

The SET was carried out on a semi-elliptical sandy track, $1,000 \mathrm{~m}$ long. The speed was checked as exhaustively as possible by the method described in detail by Agüera [1]. The time was recorded with a chronometer and an ANOVA showed the lack of significant differences between real and 
estimate velocities $(p<0.01)$.

Training program: The training usually received by the Andalusian horses in the Training and Selection Center at Jerez de la Frontera is composed by two stages: 1) First stage, lasting for 14 weeks. Its features are summarized in Table 1. 2) Second stage, lasting for 10 weeks. At the same frequency as the first stage (5 days/week), the daily schedule included 20-30 min of walking, 25-30 min of trotting and 12-18 min of galloping. The work routine was the following: 5-7 min of trotting from each hand, walkingtrotting (as a transition to galloping), 5-9 min of galloping, trotting and, finally, a few min of galloping.

Collection of data: Heart rate was recorded with a Heart Rate Meter (Polar Sport Tester) at $5 \mathrm{sec}$ intervals. Venous blood samples, collected by puncture of the external jugular vein, were obtained at rest, on finishing each level of exercise and at 2, 4, 6, 8, 10, 20 and $30 \mathrm{~min}$ of recuperation. Blood was split in two fractions. The first, placed into a tube with heparin-lithium, was immediately centrifuged in order to obtain plasma. The second fraction, poured in a tube with EDTA-3K, was destined for analysis of whole blood. Both samples were kept refrigerated until their subsequent analysis, performed within $12 \mathrm{hr}$ after their extraction.

PCV values were quantified according to the microhaematocrit method. $\mathrm{pH}$ was measured in whole blood with a pHmeter (Checker 1). Finally, plasma lactate concentrations were determined with an analyzer, following the enzymatic method (Analox, P-LM5 Champion).

Performance indexes: The following indexes have been considered in the evaluation of fitness in our Andalusian horses: 1) Maximum average heart rate (HRmax), calculated by a heart rate program computer. 2) Maximum velocity (Vmax) reached by each horse in the second phase of the SET. 3) $\mathrm{V}_{\mathrm{LA} 2}$ and $\mathrm{V}_{\mathrm{LA} 4}$, velocities which produce plasma lactate concentrations of 2 and $4 \mathrm{mmol} / \mathrm{l}$, obtained by extrapolation in the exponential curve velocity-lactate concentration. 4) Peak lactate (PLA), maximum lactate concentration, obtained at the end of the SET or at the first min of recuperation after exercise. 5) Minimum $\mathrm{pH}$ (pHmin). 6) Maximum PCV (PCVmax).

Statistical analysis: The statistical study consisted of a principal component analysis, which permitted both a study of the relations between variables (HRmax, Vmax, $\mathrm{V}_{\mathrm{LA} 2}$, $\mathrm{V}_{\mathrm{LA} 4}$, PLA, pHmin and PCVmax) and a comparison of different individuals with each other.

Principal component analysis is based on the creation of new variables_called principal components-resulting from a linear combination of the variables. The first component explains the highest percentage of the variance and the next component indicates their rank order. Thus, the first 2 principal components explain the greater part of variability. The results of the first two principal components can be plotted on a graph by the projection of the variables or of the individuals on the plan defined by the 2 principal components.

The interpretation of this analysis should consider the
Table 1. Description of the first stage of training traditionally followed in the Center of Training and Selection at Jerez de la Frontera (Spain)

\begin{tabular}{cccc}
\hline $\mathrm{N}^{\circ}$ week & Gait of horse duration $(\mathrm{min})$ & Weekly frequency \\
\hline $1-5$ & Trotting & 10 & 5 times/week \\
6 & Trotting & 15 & 5 times/week \\
$7-8$ & Trotting & 20 & 5 times/week \\
9 & Trotting & 25 & 5 times/week \\
10 & Trotting & 20 & 5 times/week \\
& Galloping & 5 & 5 times/week \\
11 & Trotting & 20 & 5 times/week \\
& Galloping & 8 & 5 times/week \\
$12-14$ & Trotting & 20 & 5 times/week \\
& Galloping & 10 & 5 times/week \\
\hline
\end{tabular}

following: 1) The greater the separation of a variable or individuals from each other, the better the discrimination between the first two components. The variables located in the center of the graph are difficult to interpret. 2) Two variables or individuals situated near together in space are positively correlated. Conversely, an important spatial separation or an opposite diagonal position shows a negative correlation between the variables or a very clear difference between individuals [12].

This method was previously applied to equine biomechanical studies [23] and fitness evaluation [2, 29].

\section{RESULTS}

In order to simplify the results, we have only taken into account the first two principal components which explain 53.97 and $23.43 \%$ of the total variation.

The values of the different fitness indexes for each horse are sumarized in Table 2. Table 3 showed the weight of each variable. The most discriminant variables have been pHmin, $\mathrm{V}_{\mathrm{LA} 4}$, PLA, HRmax, $\mathrm{V}_{\mathrm{LA} 2}$ and $\mathrm{V}_{\max }$. Differences between horses in relation to PCVmax were not detected.

All the variables have been plotted on the plan Factor $1 \times$ Factor 2, i.e., the first two principal components (Fig. 1). There are certain characteristics which have a positive relationship with the physical capacity, such as $\mathrm{V}_{\text {LA2 }}, \mathrm{V}_{\mathrm{LA} 4}$ and Vmax. On the contrary, PLA and PCVmax are negatively related to fitness. Plotting the horses in relation to the predicted value for the first two components gave us an overall view of their exercise ability. Fit horses are located on the left side of the diagram while unfit horses are located on the right. The horses have been divided in 3 groups of fitness according to the opinion of their trainers: group 1, fit horses, group 2, intermediate fitness and group 3, less fit horse (Fig. 2).

\section{DISCUSSION}

A multivariate analysis synthesizes in a graph all the data supplied by certain quantitative variables. Likewise, this method reveals the most important variables to be used to 
Table 2. Individual values for the 7 functional indexes considered in 8 Andalusian horses

\begin{tabular}{cccccccc}
\hline Horse & $\begin{array}{c}\text { HRmax } \\
\text { (beats/min })\end{array}$ & $\begin{array}{c}\text { Vmax } \\
(\mathrm{m} / \mathrm{sec})\end{array}$ & $\mathrm{V}_{\text {LA2 }}(\mathrm{m} / \mathrm{sec})$ & $\mathrm{V}_{\text {LA4 }}(\mathrm{m} / \mathrm{sec})$ & $\begin{array}{c}\text { PLA } \\
(\mathrm{mmol} / \mathrm{l})\end{array}$ & $\mathrm{pHmin}$ & $\begin{array}{c}\text { PCVmax } \\
(\%)\end{array}$ \\
\hline 1 & 199 & 9.804 & 3.07 & 5.317 & 25.2 & 6.95 & 51 \\
2 & 188 & 10 & 2.21 & 5.05 & 25.7 & 7.03 & 52 \\
3 & 192 & 10.10 & 3.68 & 5.81 & 26.4 & 7.07 & 59 \\
4 & 174 & 9.525 & 3.11 & 5.16 & 26.6 & 6.99 & 56 \\
5 & 174 & 9.525 & 3.63 & 5.56 & 26.6 & 6.99 & 56 \\
6 & 207 & 9.804 & 4.01 & 6.04 & 23.1 & 7.19 & 51 \\
7 & 218 & 9.615 & 4.22 & 6.08 & 24.4 & 7.14 & 50 \\
8 & 201 & 10.42 & 4.03 & 6.152 & 24.1 & 7.17 & 47.5 \\
\hline
\end{tabular}

Table 3. Correlations between the functional indexes considered and the first two component axes, which explain the most of the total variation (See statistical analysis)

\begin{tabular}{crr}
\hline Variable & $\mathrm{A}_{\mathrm{XIS}} 1$ & \multicolumn{1}{c}{$\mathrm{A}_{\mathrm{XIS}} 2$} \\
\hline HRmax & -0.045 & -0.864 \\
Vmax & -0.463 & -0.733 \\
$\mathrm{~V}_{\text {LA2 }}$ & -0.762 & 0.486 \\
$\mathrm{~V}_{\text {LA4 }}$ & -0.917 & 0.241 \\
PLA & 0.907 & 0.094 \\
pHmin & -0.940 & 0.233 \\
PCVmax & 0.658 & 0.228 \\
\hline
\end{tabular}

segregate horses by fitness. In our study, these factors were $\mathrm{V}_{\mathrm{LA} 2}, \mathrm{~V}_{\mathrm{LA} 4}$, Vmax and PLA. There are certain parameters which appeared to be positively correlated with a good physical capacity $\left(\mathrm{V}_{\mathrm{LA} 2}, \mathrm{~V}_{\mathrm{LA} 4}\right.$ and $\left.\mathrm{Vmax}\right)$. Other variables (PLA and PCVmax), on the contrary, seemed to exercise a negative influence on exercise tolerance.

The aerobic threshold values of the fit horses $(6,7$, and $8)$, i.e., $\mathrm{V}_{\mathrm{LA} 2}$, were higher than those determined in the remaining animals. Sloet van Oldruitenborgh-Oosterbaan et al. [24] found $\mathrm{V}_{\mathrm{LA} 2}$ higher in endurance horses, whereas the maximum workloads (maximum velocities) were not significantly different between the endurance horses and the riding-school horses. These authors, therefore, concluded that the trained endurance horses had the same speed as the riding-school horses, but they were able to perform a high submaximum workload without lactate accumulation. This fact could also be applied to horses with different level of fitness, thus, higher $\mathrm{V}_{\mathrm{LA} 2}$ values are related to better performers.

The $\mathrm{V}_{\mathrm{LA} 4}$ results of the present study remained between 5.01 and $6.152 \mathrm{~m} / \mathrm{sec}$, the latter value was for horse 8 , the animal selected by the trainers as being the fittest. This indicates that the horses with most physical aptitude need a greater intensity of exercise to reach a defined level of lactate production. These results agree with those of Wilson et al. [32] and Erikson et al. [9], but are contrary to those documented in Thoroughbred racehorses by Bayly et al. [3] and Harkins et al. [13]. The last authors reported a negative correlation between $\mathrm{V}_{\mathrm{LA} 4}$ and the running speeds for 1,200 $\mathrm{m}, 1,600 \mathrm{~m}$ and 2,000 $\mathrm{m}$ runs. Similarly, faster horses attained higher plasma lactate levels when raced over distances of 200, 300 and $400 \mathrm{~m}$ [22]. Because human middle-distance events (400-800 m) are of similar duration (about $50-120 \mathrm{sec})$ to most Thoroughbred races $(1,000$ $2,000 \mathrm{~m})$, the metabolism of successful Thoroughbred

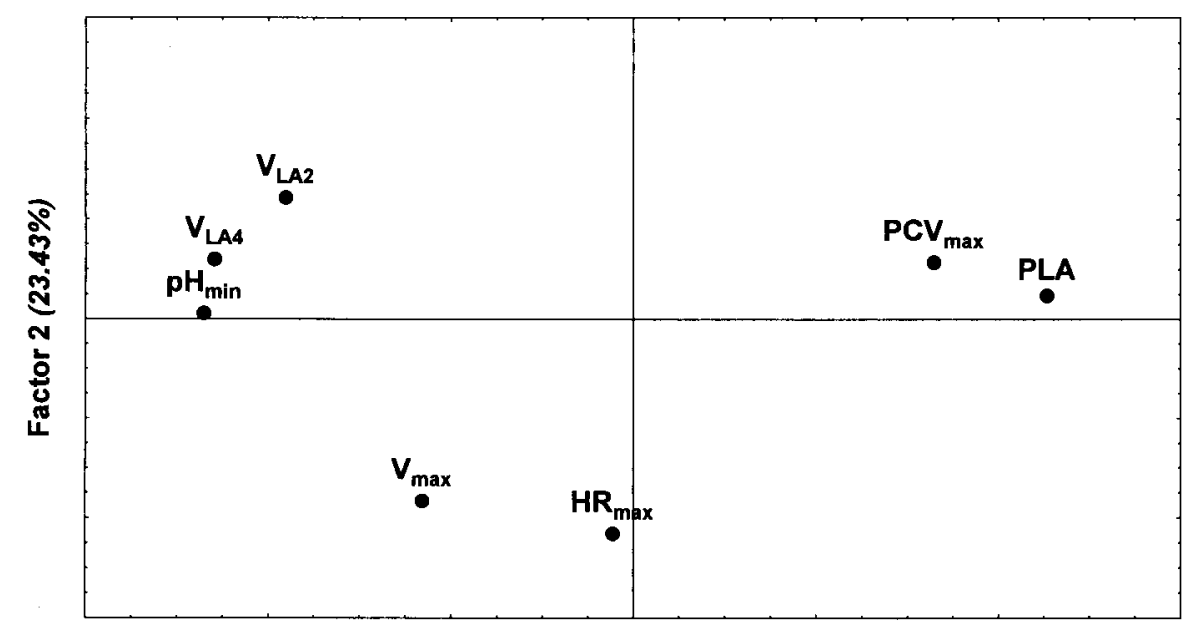

Factor 1 (53.97\%)

Fig. 1. Graph representing the coefficients for the first two principal components in the first plane of projection. 


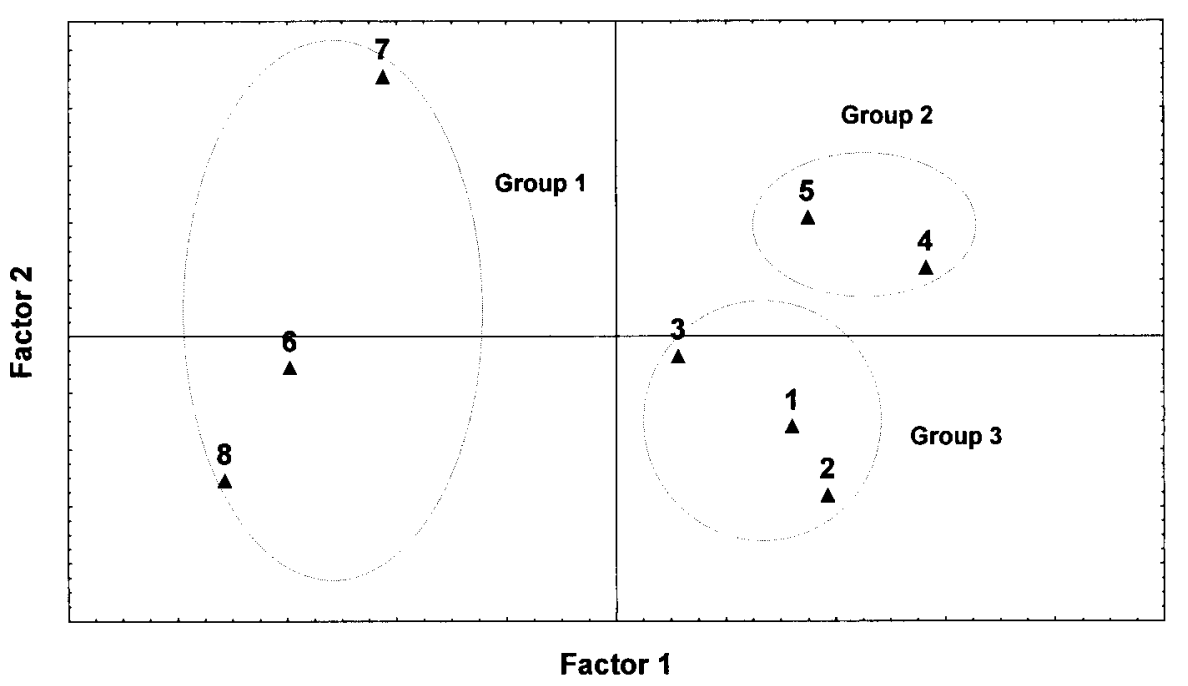

Fig. 2. Plotting of the Andalusian horses vs. the predicted values for the first and second principal components in the first plane of projection.

racehorses may be similar to the metabolism of the successful human middle-distance runners. Therefore, it appears that high, rapid lactate production is advantageous for a Thoroughbred racehorse to compete successfully. In the same way, Heck et al. [14] showed that 800 m-runners attain a $4 \mathrm{mmol} / \mathrm{l}$ plasma lactate level at a slower speed than do 1,500-m runners, and marathon runners attain that concentration at a high speed than do runner of any other distance. The explanation for this discrepancy could be dependent on the characteristics of the SET, since the intensity and the duration of the event modify the metabolic response to exercise.

On the other hand, Persson [20] described a lower value for $\mathrm{V}_{\mathrm{LA} 4}$ in horses affected by chronic obstructive pulmonary disease (COPD) due to an inferior aerobic capacity resulting from restricted alveolar ventilation. In conclusion, it appears that a higher $\mathrm{V}_{\mathrm{LA} 4}$ is a predictor of better fitness on the basis of a superior cardiorespiratory system.

High values for the aerobic and anaerobic thresholds, together with the higher maximum velocities reached by the horse during the second stage of the test were the best indicators of the superior state of fitness in horses 6,7 , and 8.

Another parameter which permitted the segregation of the horses in functional groups was PLA, although in this case its physiological interpretation was the opposite to that of the three parameters previously considered. In effect, a high PLA value implied a worse state of fitness. Increased lactic acid production has traditionally been considered to be a limiting factor for performance. Essen's [11] characterization of a good human athlete showed a lesser dependence on glycogen as an energy source with a greater consumption of lipids, which could reduce lactate production. In fact, an accumulation of this metabolite leads to a drop in the intramuscular $\mathrm{pH}$, causing the inhibition of the catalytic activity of certain enzymes which regulate the speed of the glycolytic processes, such as phosphofructokinase [18]. Likewise, a decrease in $\mathrm{pH}$ conditions changes in the permeability of the sarcolemma and interferes in the union of calcium with actinomiosin [31].

Negative consequences of lactate accumulation were demonstrated for these same horses in a previous paper [19], when an inverse correlation was found between lactate concentration after the submaximal test stage and the maximal speed.

The fittest horses $(6,7$ and 8$)$ showed the highest values for $\mathrm{pHmin}$ which ranged between 7.19 (horse 8) and 6.95 (horse 1). In virtue of this, the blood $\mathrm{pH}$ would appear to be a limiting factor for the exercise tolerance of a horse. Harkins et al. [13] give discrepant data as they found lower $\mathrm{pH}$ values for the fastest horses. This phenomenon could be attributed to the characteristics of the test. If its duration were longer, it would probably be possible to describe this inverse correlation between the pHmin and the maximum speed due to the manifestation of the biochemical cellular modifications which cause a reduction in the $\mathrm{pH}$, and condition an alteration in the functioning of the contractile myofibrillar system [26]. A buffering capacity is very important in the neutralization of the $\mathrm{H}^{+}$generated by the glycolisis and by the deionization of the lactic acid [5], with the bicarbonate system as the outstanding element. Harkins et al., in the investigation previously considered, documented a negative correlation between minimum $\mathrm{HCO}_{3}$ and the racing speed. This suggests that the fastest horses produce more lactic acid so that the $\mathrm{HCO}_{3}$ system undergoes an important reduction. In this study on 8 Andalusian horses, unfortunately, the modifications in the bicarbonate concentration were not analyzed and no comparisons could therefore be made.

Persson [20] considered the PCV value as being representative of a greater aerobic capacity. If this were so, 
the maximum value reached by the PCV would have a positive effect on performance. However, in our case, the horses with lower values of PCVmax were considered to be fitter. Various hypotheses could explain our results: 1) Boucher et al. [4], in the course of an exercise bout, observed a marked rise in the number of echinocytes, spiculated red cells. McClay et al. [17] related this finding to a depletion of electrolytes, an increase in plasma osmolality, dehydration and metabolite accumulation. The appearance of these abnormal erythrocytes has also been reported in Andalusian horses [10]. In the present study, horses with the highest PCV might display a greater number of echinocytes, thus restricting oxygen carrying capacity. 2) A higher PCVmax might signify significant losses of plasma volume from sweating and respiration [7] which could be more intense in the unfit horses. 3) According to Persson [20], during an exercise test, a fit horse shows increases in the total erythrocyte mass until a threshold is reached. Similarly, values of over $49 \%$ for PCV were considered by Marbach [16] as adverse for performance by an equine athlete. 4) Finally, excessive polyglobulia implies an alteration in blood viscosity which would inhibit liberation of oxygen to the tissues [17]. Therefore, horses with high PCVmax (2, 3 and 4) showed a lesser fitness level.

The influence of HRmax on the physical capacity of the 8 horses evaluated was difficult to assess. As is shown in Table 2, the HR of the three horses with the best results in the test $(6,7$ and 8$)$ exceeded 200 beats/min, despite the correlation between elevated HR, injury and/or fatigue which has been documented in human runners [30] and swimmers [8]. Cardiac output (Q) increases with exercise as a function of heart rate and stroke volume, although at high speeds, Q depends on the rise in the heart rate. Thus, the higher number of beats per min of horses 6,7 and 8 would have triggered greater cardiac output and, therefore, would have provided more oxygen to the active muscles. The capacity of the tissues to extract oxygen and the organism's ability to mobilize oxygen must also be considered. Another point to take into account is the higher velocity reached by these horses, which could cause the higher heart rate.

In conclusion, a principal component analysis enabled us to segregate the 8 Andalusian horses studied into different groups according to their physical potential in spite of the homogeneity of the training, sex, age, feeding and handling. The most discriminant variables were $\mathrm{V}_{\mathrm{LA} 2}, \mathrm{~V}_{\mathrm{LA} 4}$, PLA, pHmin and Vmax.

ACKNOWLEDGMENTS. The authors would like to thank the Center of Selection and Training at Jerez de la Frontera (Spain), without whose support this paper could not have been completed. The help of Mr. Joaquín Reyes in the statistical analysis is much appreciated.

\section{REFERENCES}

1. Agüera, E. I. 1994. Evaluación de la capacidad aerobia en la predicción de aptitud para el esfuerzo en el caballo Pura Raza Española. In: PhD Thesis, Universidad de Córdoba, España.

2. Barrey, E., Valette, J. P., and Wolter, R. 1989. Etude multifactorielle de l'aptitude à l'effort chez le cheval de sells. Ann. Zootech. 38: 157-169.

3. Bayly, W. M., Grant, B. D., and Pearson, R. C. 1987. Lactate concentrations in Thoroughbred horses following maximal exercise under field conditions. pp. 426-437. In: Equine Exercise Physiology 2 (Gillespie, J. R. and Robinson, N. E. eds.), ICEEP Publications, Davis, CA.

4. Boucher, J. H., Ferguso, E. W., Wilhelmsen, C. L., Statham, N., and McMeeking, R. R. 1981. Erythrocyte alterations during endurance exercise in horses. J. Appl. Physiol. 51: 131-140.

5. Brien, M. D. and McKenzie, D. C. 1989. The effect of induced alkalosis and acidosis on plasma lactate and work output in elite oarsmen. Eur. J. Appl. Physiol. 58: 797-802.

6. Castejón, F., Rubio, D., Tovar, P., Vinuesa, M., and Riber, C. 1994. A comparative study of aerobic capacity and fitness in three different horse breeds (Andalusian, Arabian and AngloArabian). J. Vet. Med., A 41: 645-652.

7. Cohen, N. D., Roussel, A. J., Lumsden, J. H., Cohen, A. C., Grift, E., and Lewis, C. 1993. Alterations of fluid and electrolyte balance in Thoroughbred racehorses following strenuous exercise during training. Can. J. Vet. Res. 57: 913.

8. Counsilman, J. E. 1968. The science of swimming. In: Prentice Hall Inc., Englewood Cliffs, N. J.

9. Erikson, H. H., Erikson, B. K., Lundin, C. S., Gillespie, J. R., and Coffman, J. R. 1991. Performance indices for evaluation of the equine athlete. pp. 457-469. In: Proceedings of 36th Ann. Conv. Am. Assoc. Equine Pract. Lexington Kentucky.

10. Escribano, B. M. 1994. Respuesta de diversos parámetros hemáticos en caballos P. R. E. sometidos a un ejercicio de intensidad creciente. In: Tesina de Licenciatura. Universidad de Córdoba. España.

11. Essen, B. 1977. Intramuscular substrate utilization during prolonged exercise. Ann. Proc. New York Acad. Sci. 301: 30-44.

12. Foucart, T. 1985. Analyse factorielle: programmation sur micro-ordinateurs. In: Coll "Méthodes Programme", Mason, Paris.

13. Harkins, J. D., Beadle, R. E., and Kamerling, S. G. 1993. The correlation of running ability and physiological variables in Thoroughbred racehorses. Equine Vet. J. 25: 53-60.

14. Heck, H., Mader, A., Hess, G., Mucke, S., Muller, R., and Hollman, W. 1985. Justification of the 4-mmol/l lactate threshold. Int. J. Sports Med. 6: 117-130.

15. Holmes, J. R. and Rezakhani, A. 1975. Observations of the T wave of the equine electrocardiogram. Equine Vet. J. 7: 5562 .

16. Marbach, W. 1978. Parámetros hematológicos demonstrando la aptitud en caballos de carreras y el efecto de Conforta/ Catosal sobre el caballo de carreras. Vet. Med. Rev. 1: 82-92.

17. McClay, C. B., Weiss, D. J., Smith, C. M., and Gordon, B. 1992. Evaluation of hemorrheologic variables as imlications for exercise induced pulmonary hemorrhage in racing Thoroughbreds. Am.J. Vet. Res. 53: 1380-1385.

18. McCutcheon, L. J., Byrd, S. K., and Hodgson, D. R. 1992. Ultrastructural changes in skeletal muscle after fatiguing exercise. J. Appl. Physiol. 72: 1111. 
19. Muñoz, A., Santisteban, R., Rubio, M. D., Vivo, R., Agüera, E. I., and Castejón, F. M. 1996. Cinética del lactato plasmático durante el ejercicio y recuperación en caballos Pura Raza Española. Med. Vet. 13: 283-290.

20. Persson, S. G. B. 1983. Evaluation of exercise tolerance and fitness in the performance horse. pp. 441-447. In: Equine Exercise Physiology (Snow, D. H., Persson, S. G. B., and Rose, R. J. eds.), Granta Editions, Cambridge, U.K.

21. Rubio, D., Riber, C., Santisteban, R., Tovar, P., and Castejón, F. M. 1994. Hematologic alterations as an index of exercise tolerance in different breeds of horses. Equine Ath. 7: 10-17.

22. Saibene, F., Cortili, G., Gavazzi, P., Sala, A., Faina, M., and Sardella, F. 1985. Maximal anaerobic (lactic) capacity and power of the horse. Equine Vet.J. 17: 130-132.

23. Silver, I. A., Brown, P. N., and Goodship, A. E. 1983. Biomechanical assessment of locomotor performance in the horse. Equine Vet.J. 1: 23-25.

24. Sloet van Oldruitenborgh-Oosterbaan, M. M., Welsing, Th., and Breukink, H. J. 1987. Standardized exercise test on a track to evaluate fitness and training on saddle horses. pp. 6876. In: Equine Exercise Physiology 2 (Gillespie, J. R. and Robinson N. E., eds.), ICEEP Publications, Davis, CA.

25. Snow, D. H. 1983. Skeletal muscle adaptations: a review. pp. 160-183. In: Equine Exercise Physiology (Snow, D. H., Persson, S. G. B., and Rose, R. J. eds.), Granta Editions, Cambridge, U. K.

26. Spriet, L. L., Soderlund, K., Bergstrom, M., and Hultman, E.
1987. Skeletal muscle glycogenolysis, glucolysis and $\mathrm{pH}$ during electrical stimilation in men. J. Appl. Physiol. 62: 616-621.

27. Steel, J. R. 1966-67. The equine electrocardiogram and the Heart Score concept. Vict. Vec. Proc. 25: 84.

28. Straub, R., Dettwiler, M., Hoppeler, H., and Claasen, H. 1983. The use of morphometry and enzyme activity measurements in skeletal muscles for the assessment of the working capacity of horses. In: Equine Exercise Physiology (Snow, D. H., Persson, S. G. B., and Rose, R. J. eds.), Granta Editions, Cambridge, U. K.

29. Valette, J. P., Barrey, E., and Wolter, R. 1991. Multivariate analysis of exercise parameters measured during an incremental treadmill test. pp. 337-342. In: Equine Exercise Physiology 3 (Persson, S. G. B., Lindholm, A., and Jeffcott, L. B. eds.), ICEEP Publications, Davis, California.

30. Wallingford, R. 1975. Long distance running. In: The Scientific Aspects of Sports Training (Taylor, A. W. ed.), Charles C. Thomas Publisher, Springfield, IL.

31. Wenger, H. A. and Reed, A. T. 1976. Metabolic factors associated with muscular fatigue during aerobic and anaerobic work. Can. J. Appl. Sports Sci. 1: 43-48.

32. Wilson, R. G., Isler, R. B., and Thornton, J. R. 1983. Heart rate, lactic acid production and speed during a standardized exercise test in Standardbred horses. In: Equine Exercise Physiology (Snow, D. H., Persson, S. G. B., and Rose, R. J. eds.), Granta Editions, Cambridge. 